JURNAL

SENGKETA USAHA PERTAMBANGAN

DI WILAYAH HUTAN ELANG DODO

KABUPATEN SUMBAWA

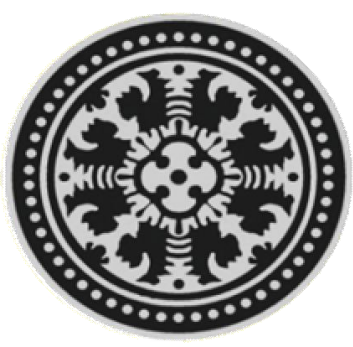

IWAN HARIANTO

NIM: 0990561053

\author{
PROGRAM MAGISTER \\ PROGRAM STUDI ILMU HUKUM \\ PROGRAM PASCASARJANA \\ UNIVERSITAS UDAYANA \\ DENPASAR \\ 2012
}




\title{
SENGKETA USAHA PERTAMBANGAN \\ DI WILAYAH HUTAN ELANG DODO \\ KABUPATEN SUMBAWA
}

\author{
IWAN HARIANTO \\ NIM: 0990561053
}

\begin{abstract}
West Nusa Tenggara, one of the regions rich in minerals mining. One of the mining companies doing business in the region is PT. Newmont. In 2003 the company was exploring the forest areas Elang Dodo Sumbawa. The presence of PT. Newmont in the region are not well received by the villagers of Lebangkar, resulting in rejection of the action in 2004 by way of demonstration and boycott the company's activities. Of the incident raises some issues: (1) who is the subject and what the object of the dispute? (2) how the process and the factors that cause disputes? (3) how the settlement of the dispute?

The research method used in this research is an empirical law is derived from the analytical descriptik field data and data library. Processing and data analysis conducted qualitatively. Discussion until the conclusion in this paper can be described as follows: (1) subject to the dispute that is the village of Lebangkar with PT. Newmont and the Government of Sumbawa. The subject of dispute in the form of contract work necking VI results in 2005 with an area of 87,500 ha. (2) The process of dispute which originated from exploration PT. Newmont in the woods Elang Dodo conducted in 2003. This exploration spawned several factors contributing to the dispute; violation of customs, reduced sources of income, lack of socialization, and control of natural resources. (3) dispute settlement efforts, through litigation and non-litigation. Settlement was not effective due; substance law, legal culture and legal structure.
\end{abstract}

Keywords: Disputes, Mining, Forest Elang Dodo

\section{PENDAHULUAN}

\subsection{Latar Belakang}

Nusa Tenggara Barat salah satu daerah yang kaya bahan galian, baik galian logam maupun non logam. Bahan galian logam berupa emas, perak, tembaga, pasir, dan timbal, sedangkan bahan galian non logam berupa batu apung, batu gamping, 
sirtu, marmer dan lain-lain. ${ }^{1}$ Salah satu perusahaan pertambangan yang melakukan usaha pertambangan di daerah tersebut adalah Newmont Gold Company (PT. Newmont) melalui kontrak karya yang di buat pada tanggal 6 November 1986 oleh Pemerintah RI. ${ }^{2}$ Atas persetujuan itu, pada tahun 1996 perusahaan tersebut melakukan usaha ekplorasi yang pertama kali di wilayah Batu Hijau Kabupaten Sumbawa Barat dengan luas 550.856 ha, kemudian dilajutkan dengan usaha ekploitasi, dalam sehari usaha ini mampu meraup sekitar 6.250 ton kosentrat (biji mas, tembaga dan mineral lainnya).

Keberadaan perusahaan PT. Newmont di wilayah Batu Hijau tidak selamanya akan eksis melakukan usaha pertambangan, karena cadangan mineral yang bersifat terbarukan yang terkadung di wilayah tersebut kemungkinan akan habis. Sebagai wilayah perluasannya adalah wilayah hutan Elang Dodo yang berada di Kabupaten Sumbawa. Pada tahun 2003, awal kegiatan ekplorasi PT. Newmont di wilayah Hutan Elang Dodo. Selama ekplorasi PT. Newmont di wilayah tersebut, banyak memberikan berbagai dampak positif bagi masyarakat setempat, misalnya dapat

\footnotetext{
${ }^{1}$ Anonim, 2011. "Potensi NTB". Serial Online Juni 2012, Available From: URL: hhtp://ntb.go.id/deskripsiwilayah/petasumberdaya. Di akses pada tanggal 3 Juni 2012

${ }^{2}$ Salamudin Daeng, 2010. Investment Colonial Model (Critical Analysis On Investment Law In Indonesia). Institute For Global Justice (IGJ), Jakarta Selatan, hal., 40
}

memperkerjakan tenaga kerja sebanyak 100 orang dan memberikan manfaat bagi pengusaha lokal, di mana pengusaha tersebut dapat mendistribusikan berbagai kebutuhan para tenaga kerja yang diperkerjakan oleh PT. Newmont. ${ }^{3}$ Namun, kegiatan ekplorasi tersebut tidak begitu lama, karena adanya gugatan dari masyarakat Desa Lebangkar. Masyarakat Desa Lebangkar menginginkan agar PT. Newmont harus menghentikan aktivitas ekplorasi dan sekaligus hengkang di tanah leluhur masyarakat Desa Lebangkar. Wujud gugatan masyarakat dilancarkan melalui demontrasi, baik ke kantor PT. Newmont maupun ke Pemerintah Sumbawa.

Akibat gugatan itu, Pemerintah Kabupaten Sumbawa menanggapi dengan serius dengan membentuk tim investigasi guna mensosialisasi keberadaan ekplorasi PT. Newmont di wilayah hutan Elang Dodo kepada masyarakat Desa Lebangkar. Sosialisasi ini tidak berhasil, justru yang terjadi memancing emosional masyarakat sehingga terjadi tindakan anarkis. ${ }^{4}$ Akibat dari itu, akhirnya warga Desa Lebangkar melakukan aksi dan memperluas perlawanan terhadap PT. Newmont dengan melibatkan seluruh elemen rakyat se Kecamatan

3 Gaung NTB. "PT. Newmont Memberi Kontribusi Bagi Masyarakat Sekitar”. Tanggal 25 September 2004, hal., 1

${ }^{4}$ Gaung NTB, 2004. "Penyanderaan Dua Staff PT. Newmont Oleh Masyarakat Desa Lebangkar". Tanggal 23 Oktober, hal., 1, kolom., 1 
Ropang. ${ }^{5} \quad$ Sebagai akumulasi kemarahan rakyat Kecamatan Ropang terhadap PT. Newmont akibat tidak adanya itikad baik, maka pada tanggal 18 Maret 2006 masyarakat sekecematan Ropang sepakat untuk melakukan pembubaran terhadap aktivitas PT. Newmont. Pembubaran tersebut, berujung pada pembakaran camp milik sub kontraktor PT. Newmont yang sedang melakukan ekplorasi di kawasan hutan Elang Dodo. ${ }^{6}$

Kejadian di atas, dalam perkembangannya belum menemukan titik terang atau belum kunjung selesai, sehingga tidak menutup kemungkinan masalah ini akan muncul kembali sewaktu-waktu. Ketika masalah ini muncul, maka akan berdampak buruk bagi investas pertambangan di Indonesia. Oleh karena itulah, peneliti terdorong untuk mengkaji dan meneliti masalah tersebut, guna mengetahui segala problem yang menyangkut dengan masalah itu secara komprehensif.

\subsection{Rumusan Masalah}

Berdasarkan latar belakang di atas, diajukan rumusan masalah yang diangkat dalam penelitian ini, yaitu:

5 JATAM, 2006. "PT. Newmont Memperluaskan Kerusakan Hutan Elang Dodo". Serial Online Pebruari 2011, Available From: URL: hhtp:/www.jatam.or. Di akses pada tanggal 21 Pebruari 2011

${ }^{6}$ IMC, 2006. "Kronologis Penembakan Warga Desa Ropang Dalam Aksi Penolakan PT. Newmont". Serial Online Pebruari 2011, Available From: URL: hhtp:/www.aifkmultiply.com. Di akses pada tanggal 22 Pebruari 2011 a. Siapa yang menjadi subyek dan apa yang menjadi obyek sengketa usaha pertambangan di wilayah hutan Elang Dodo?

b. Bagaimana proses dan faktor penyebab terjadinya sengketa usaha pertambangan di wilayah hutan Elang Dodo?

c. Bagaimana upaya penyelesaian sengketa usaha pertambangan di wilayah hutan Elang Dodo?

\subsection{Tujuan Penelitian}

1.3.1. Tujuan umum:

Secara umum tujuan penelitian ini, yaitu untuk mengkaji sengketa usaha pertambangan di wilayah hutan Elang Dodo Kabupaten Sumbawa.

\subsubsection{Tujuan khusus}

Adapun tujuan khusus dari penelitian ini sebagai berikut:

a. Untuk mengetahui dan mengidentifikasikan sekaligus menganalisis secara kritis subyek dan obyek sengketa

b. Untuk mengetahui dan menganalisis secara kritis proses dan faktor-faktor penyabab terjadinya sengketa

c. Untuk mengetahui dan mengidentifikasikan dan menganalisis secara kritis upaya penyelesaian sengketa.

\section{METODE PENELITIAN}

Jenis penelitian yang digunakan dalam penelitian ini adalah penelitian ilmu 
hukum empiris dengan mengkaji dan meneliti sengketa usaha pertambangan di wilayah hutan Elang Dodo Kabupaten Sumbawa. Sifat penelitian ini deskriptif analitik, di mana menggambarkan secara tepat sengketa usaha pertambangan tersebut dengan mengidentifikasikan gejala atau hubungan antara subyek yang satu dengan subyek yang lain di dalam masyarakat. ${ }^{7}$

Jenis data yang digunakan dalam penelitian ini adalah data lapangan dan data kepustakaan. Sumber data yang digunakan dalam penelitian ini, bersumber dari data lapangan dan data kepustakaan. Data lapangan dalam penelitian ini, bersumber dari hasil penelitian langsung di lapangan, melalui informan dan responden, sedangkan data kepustakaan, bersumber dari bahan hukum dan bahan non hukum. Bahan hukum bersumber dari bahan hukum primer dan bahan hukum sekunder. Bahan hukum primer yang digunakan dalam penelitian ini, yaitu Undang-Undang Dasar 1945 Negara Republik Indonesia, Undang-Undang No. 4 Tahun 2009 Tentang Pertambangan Mineral Dan Batu Bara, Undang-Undang No. 41 Tahun 1999 Tentang Kehutanan, dan Kontrak Karya PT. Newmont dan Pemerintah Republik Indonesia pada tahun 1986, sedangkan bahan hukum sekunder yaitu hasil-hasil penelitian hukum, pendapat

7 Program Studi Magister Ilmu Hukum, Program Pasca Sarjana Universitas Udayana, 2005. Pendoman Penulisan Usulan Penelitian Dan Penulisan Tesis Ilmu Hukum, hal., 37 para pakar hukum, dan lain-lain. Untuk bahan non hukum, berupa artikel yang di muat di media massa atau media online yang memiliki relevansi dengan permasalahanan yang diteliti dan dikaji dalam penelitian ini.

Teknik pengumpulan, data kepustakaan menggunakan sistem kartu sedangkan data lapangan menggunakan teknik wawancara. Data yang sudah terkumpul kemudian diolah dan di analisis dengan menggunakan analisis kualitatif, di mana semua data tersebut di susun secara sistematis dan digolongkan dalam pola dan thema kemudian dihubungkan antara data satu dengan data lainnya. Kemudian dilakukan interprenstasi guna memahami makna dari keseluruan kualitas data, sehingga memperoleh gambaran terhadap permasalahananan yang diteliti. Setelah itu usai, tahapan selanjutnya dilakukan penyajian data hasil penelitian dengan cara deskriptifanalitik.

\section{HASIL DAN PEMBAHASAN}

\subsection{Subyek Dan Obyek Yang Di Sengketa}

\subsubsection{Pihak yang bersengketa}

Pada umumnya dalam suatu sengketa, sekurang-kurangaya terdapat dua pihak yang berseteru yaitu pihak penggugat (eiser, plainitif) atau pihak yang mengajukan gugatan dan pihak tergugat (gedaagde, defendant). Pihak penggugat adalah orang atau badan hukum yang merasa dirugikan oleh pihak tergugat, sehingga mengajukan 
gugatan atau meminta perlindungan hukum, sedangkan pihak tergugat, yaitu pihak atau orang atau badan hukum yang mengeluarkan keputusan berdasarkan kewenangan yang diberikan kepadanya sehingga keputusan yang dikeluarkanya di gugat oleh para pihak atau orang maupun badan hukum. ${ }^{8}$

Di dalam antropologi hukum dijelaskan mengenai subyek (pihak) yang bersengketa. Hal ini disampaikan oleh Comaroff dan Roberts, yang dikutif dalam tulisan Valerine J.L Kriekhoff, yakni individu dengan individu dan kelompok dengan kelompok (antar kelompok atau intra group). ${ }^{9}$ Dalam masyarakat moderen, benturan-benturan kepentingan antar individu atau kelompok dalam masyarakat mungkin saja terjadi antar individu atau kelompok dalam komunitas. Melainkan bisa juga terjadi sengketa antar individu atau kelompok yang ada dalam suatu komunitas dengan pihak di luar komunitas, misalnya lembaga pemerintah maupun swasta.

Di dalam dunia pertambangan juga di kenal sengketa antar para pihak. Para pihak tersebut, yakni sengketa antar negara, sengketa host country dengan investor, sengketa investor asing dengan mitra lokalnya, sengketa investor dengan masyarakat setempat, sengketa antara

\footnotetext{
${ }^{8}$ Martitah dan Hery Abduh S, 2005. Buku Ajar Hukum Acara PTUN. UGM, Yogyakarta, hal., 25

9 Valerine J.L Kriekhoff, 2001. Mediasi (Tinjauan Dari Segi Antropologi Hukum). Dalam Antropologi Hukum: Sebuah Bunga Rampai oleh T.O. Ihromi. Yayasan Obor, Jakarta, hal., 225
}

pemerintah pusat dengan pemerintah daerah, sengketa antar pemerintah daerah, sengketa antar intasi pemerintah pusat, dan sengketa antar pemegang KP atau kontraktor PKP2B. ${ }^{10}$

Penyataan diatas, bila relepansikan dengan para pihak yang bersengketa dalam usaha pertambangan di wilayah hutan Elang Dodo Kabupaten Sumbawa, maka pihak yang bersengketa adalah kelompok dengan kelompok yakni antara masyarakat dengan perusahaan asing (investor) dan pemerintah daerah. Masyarakat yang diwakili oleh Forum Masyarakat Desa Lebangkar sedangkan perusahaan asing (investor) dan pemerintah daerah yakni PT. Newmont dan Pemerintah Kabupaten Sumbawa. Masyarakat Desa Lebangkar yang diwakili oleh Forum Masyarakat Desa Lebangkar merasa keberatan dengan ekplorasi PT. Newmont di wilayah hutan Elang Dodo karena tanpa adanya sosialisasi ke masyarakat Desa Lebangkar. Keberatan ini bukan hanya ditujukan ke PT. Newmont akan tetapi ke Pemerintah Kabupaten Sumbawa, karena keberadaan ekplorasi PT. Newmont di wilayah hutan Elang Dodo tidak bisa lepas dengan campur tangan pemerintah daerah yang didasarkan pada asas otonomi daerah.

\subsubsection{Obyek sengketa}

\footnotetext{
${ }^{10}$ Supancana dkk, 2009. Penyelesain Sengketa Di Bidang Pertambangan. Badan Pembinan Hukum Nasional Departeman Hukum dan HAM, Jakarta, hal., 16
} 
Berdasarkan hasil penelitian, bahwa obyek sengketa usaha pertambangan di wilayah hutan Elang Dodo yaitu kontrak karya. Menurut Salim, HS bahwa kontrak karya adalah suatu perjanjian yang dibuat antara pemerintah Indonesia/ pemerintah daerah dengan kontraktor asing semata-mata dan/atau merupakan patungan antara badan hukum asing dengan badan hukum domistik untuk melakukan kegiatan ekplorasi maupun ekploitasi dalam bidang pertambangan umum, sesuai dengan jangka waktu yang disepakati oleh kedua belah pihak. ${ }^{11}$

Adapun kontrak karya yang menjadi obyek sengketa yakni perjanjian yang di buat dan disepakati oleh pemerintah RI dengan Newmont Gold Company (AS), yang berorientasi pada emas, tembaga dan mineral-mineral lainnya di wilayah Nusa Tengara Barat. Perusahaan tersebut telah mendapat persetujuan dari Presiden RI Nomor NP.B-43/Pres/XI/1986 Tertanggal 6 November 1986. Sehingga dilegalisir menjadi suatu badan hukum Indonesia dengan Akte Notaries Nomor 164 tanggal 18 November 1986 dan beserta surat keputusan Menteri Kehakiman RI Nomor C2-82 55 HT.01.01 Tahun 1986 tanggal 26 November 1986. Dengan luas konsensi areal berdasarkan kontrak karya generasi ke-4 yang ditandatangani oleh PT. Newmont pada

\footnotetext{
${ }^{11}$ H. Salim, HS, 2004. Hukum Pertambangan Di Indonesia. PT. Raja Grafindo Persada, Jakarta, hal., 178
}

tahun 1986 adalah sebesar 1.127.134 hektar. 12

Kontrak karya tersebut di buat pada tahun 1986, sehingga yang memiliki kewenangan adalah Pemerintah Pusat yang diwakili oleh Menteri Energi dan Sumberdaya Mineral. Setelah begulirnya otonomi daerah, maka pemerintah daerah, baik pemerintah propinsi maupun pemerintah kabupaten/ kota yang didasarkan pada Peraturan Pemerintah Nomor 75 Tahun 2001 tentang Perubahan Kedua Atas Peraturan Pemerintah Nomor 32 Tahun 1969 tentang Pelaksanaan Undang-Undang Nomor 11 tahun 1967 tentang Ketentuan Pokok Pertambangan, maka inti dari isi peraturan tersebut, bahwa pejabat yang menandatangi kontrak karya adalah bupati/walikota, gubernur dan menteri energi dan sumberdaya mineral. Dengan diberlakukan peraturan pemerintah tersebut, sehingga terjadi perubahan signifikan pada luas kontrak karya PT. Newmont di Pulau Sumbawa. Hal ini didasarkan pada Keputusan Menteri Energi Sumberdaya Mineral Nomor: 398.K/40.0/DJG/2005 tanggal 10 Oktober 2005 yang merupakan penciutan VI seluas 87.500 Ha yang terbagi kedalam pinjam pakai seluas $6.417,30 \mathrm{Ha}$ dan areal ekplorasi seluas 81.122,70 Ha. Dari seluruh wilayah tersebut, terbagi dalam kawasan hutan \pm

\footnotetext{
${ }^{12}$ Departemen Pertambangan RI, 2004. "Luas Areal Kontrak Karya PT.Newmont". Jakarta, tertanggal 12 Maret.
} 
67.968 Ha dan areal penggunaan lain (APL) dan laut seluas $\pm 13.154 .70 \mathrm{Ha}$.

Untuk melakukan ekplorasi PT. Newmont di wilayah hutan, maka perlu mendapat ijin dari pihak kehutanan. Berdasarkan data dari Dinas Kehutanan Propinsi NTB dengan Nomor surat: 522/2049.1/PPH/Dishut tentang Daftar Luas Penggunaan Kawasan Hutan Untuk Kegiatan Ekplorasi Tembaga Emas PT. Newmont khususnya di wilayah hutan Elang Dodo Kabupaten Sumbawa, yakni seluas 16.568,54. Atas kebijakan itulah, sehingga pada tahun 2003 PT. Newmont memperluas wilayah ekplorasinya di hutan Elang Dodo. Selama kurang lebih satu tahun perusahaan tersebut melakukan ekplorasi di wilayah hutan Elang Dodo. Pada tahun 2004 perusahaan tersebut mendapat gugatan dari masyarakat Desa Lebangkar. Gugatan yang lakukan oleh masyarakat Desa Lebangkar yakni melalui jalur non litigasi, dengan cara pendekatan persuasif dan aksi demontasi ke PT. Newmont dan Pemerintah Daerah Sumbawa. Isi dari gugatan tersebut, yakni masyarakat Desa Lebangkar merasa keberatan dengan ekplorasi PT. Newmont di hutan Elang Dodo. Keberadaan perusahaan tersebut di hutan Elang Dodo telah mengangu kebiasaan masyarakat Desa Lebangkar untuk memanfaatkan tanah leluhurnya, seperti berburu, bejalit (membuat gula dari air enau), mengambil madu, memetik hasil perkebunan, dan menjalankan ritualitas keagamaan. Selain itu, ekplorasi PT. Newmont secara tidak langsung telah mengambil hak-hak masyarakat Desa Lebangkar berupa bekas perkampungan, sawah, kebun dan kuburan leluhur masyarakat Desa Lebangkar.

\subsection{Proses Dan Faktor-Faktor Penyebab Terjadinya Sengketa}

\subsubsection{Proses terjadinya sengketa}

Hutan Elang Dodo merupakan tanah leluhur dan wilayah ritualitas keagamaan masyarakat Desa Lebangkar. Hal ini didasarkan pada masih adanya kuburan masal nenemoyang masyarakat Desa Lebangkar, sehingga pada hari-hari besar keagamaan masyarakat Desa Lebangkar sering melakukan ziarah kubur di wilayah tersebut, seperti pada hari raya Idul Fitri dan lain-lain.

Walaupun hutan Elang Dodo adalah wilayah adat masyarakat Desa Lebangkar, akan tetapi wilayah tersebut masuk dalam katagori hutan negara, hal ini didasarkan pada penunjukan sebagai kawasan hutan sesuai dengan Keputusan Menteri Pertanian RI Nomor 756/Kpts/Um/10/1982 tanggal 12 Oktober 1982. Pengakuan dan kesepakatan multipihak yang dituangkan dalam berita acara panitia tatabatas (BATB) pada tanggal 13 Maret 1989 dan disahkan tanggal 19 Mei 1989 dengan hasil pengukuhan dan tata batas luar diperoleh luas definitif 119.675,30 Ha. ${ }^{13}$

13 Tim Evaluasi: Dinas Kehutanan Propinsi NTB, Biro Ekonomi Sekretaris Daerah Propinsi NTB, 
Atas dasar itulah sehingga pemerintah memberi ijin ekplorasi PT. Newmont di wilayah hutan Elang Dodo pada tahun 2003. Ekplorasi tersebut secara langsung telah menimbulkan persolan di tengah-tengah masyarakat Desa Lebangkar dikarenakan tanpa ada pemberitahuan kepada masyarakat Desa Lebangkar. Kemudian ekplorasi tersebut telah menimbulkan sikap para pejabat tinggi yang duduk di jajaran Pemerintahan Kabupaten Sumbawa dan masyarakat luar (masyarakat di luar Desa Lebangkar) untuk memiliki hutan Elang Dodo menggunakan SPPT.

Permasalahan tersebut baru tercium oleh masyarakat Desa Lebangkar pada tahun 2004. Akibat dari itu sehingga seluruh elemen masyarakat Desa Lebangkar yang tergabung dalam Forum Masyarakat Desa Lebangkar mempertanyakan persolan tersebut kepada pemerintah dan pihak PT. Newmont dengan cara pedekatan persuasif, tapi pihak Pemerintah Kabupaten Sumbawa dan PT. Newmont selalu berbelit dan menganulir persolan tersebut. Akibat dari itu, masyarakat Desa Lebangkar melibatkan pihak DPRD Sumbawa untuk menegur Pemerintah Sumbawa dan PT. Newmont

Dinas Perkebunan dan Pertanian Kabupaten Sumbawa Barat, Dinas Kehutanan Perkebunan Kabupaten Sumbawa dan Balai Pemantapan Kawasan Hutan Wilayah VIII. Laporan Hasil Evalusa; Penggunaan Kawasan Hutan Untuk Ekplorasi Tambang Tembaga, Emas Dan Mineral Pengikutnya Atas Nama PT. Newmot Di Kabupaten Sumbawa Barat dan Kabupaten Sumbawa Propinsi NTB Priode Agustus 2007 Sampai Dengan Agustus 2009. untuk mensosialisasikan keberadaan PT. Newmont di wilayah hutan Elang Dodo dan pembatalan penerbitan SPPT hutan Elang Dodo, tapi pihak pemerintah tidak gerah dengan teguran DPRD Sumbawa. Sebagai akumulasi dari sikap Pemerintah Sumbawa dan PT. Newmont akhirnya masyarakat Desa Lebangkar melakukan pemboikotan aktivitas PT. Newmont di hutan Elang Dodo.

3.2.2. Faktor-faktor penyebab terjadinya sengketa

Menurut Made Widnyana bahwa konflik dapat disebabkan dan dipengaruhi oleh berbagai banyak faktor; sistem nilai dan kepercayaan, sistem informasi, kekurangan sumber, ketidakpuasan dari suatu keinginan, persaingan antara perusahaan yang mengarah pada permusuhan, peraturan dan perundangudangan, adat, pola dan pelaksanaan, kebiasaan, dan ego. ${ }^{14}$

Penyataan di atas, bila dihubungkan dengan faktor yang menyebabkan terjadinya sengketa usaha pertambangan di wilayah hutan Elang Dodo, maka ada beberapa faktor yang masuk dalam katagori yang menyebabkan terjadinya sengketa, diantaranya:

1. Dilanggarnya kebiasaan (adat istiadat)

Kebiasaan yang dilakukan oleh warga Desa Lebangkar terhadap hutan Elang Dodo, yakni dengan memanfaatkan hutan Elang Dodo sebagai tempat ritualitas

14 Made Widnyana, 2007. Alternatif Penyelesaian Sengketa (ADR). Jakarta, Indonesia Business Law Center (IBLC), hal., 57-58 
keagaman, seperti ziarah kubur dan bayar nazar. Ziarah kubur biasanya dilakukan pada hari-hari besar keagaman, yakni pada hari raya Idil Fitri, sedangkan bayar nazar merupakan sesuatu ritualitas yang dilakukan pada hari-hari tertentu, misalnya salah satu warga Desa Lebangkar yang terkena kunakuna, apabila ia sembuh, maka wajib hukumnya membayar nasar dengan cara meyembele satu ekor ternak. Kebiasaan ini sudah lama dilakukan oleh masyarakat Desa Lebangkar, mulai dari jaman nenekmoyang hingga sekarang.

Kebiasaan yang dilakukan oleh masyarakat Desa Lebangkar dapat dikatakan adat istiadat. Adat istiadat menurut Soerjono Soekanto, adalah suatu kebiasaan yang dilakukan oleh salah satu komunitas guna menjauhkan diri dari perbuatan buruk yang diajurkan oleh aturan yang berlaku dalam komunitas tersebut. ${ }^{15}$

Kebiasaan atau adat istiadat masyarakat Desa Lebangkar ini merasa terganggu semenjak ekplorasi PT. Newmont di hutan Elang Dodo. Semua wilayah tempat diselenggarakan adat istiadat masuk wilayah ekplorasi PT. Newmont, sehingga secara tidak langsung PT. Newmont telah melanggar kearifan lokal masyarakat Desa Lebangkar.

2. Kekurangan sumber pendapatan

\footnotetext{
${ }^{15}$ Soerjono Soekanto, 1988. Pokok Sosilogi Hukum. PT. Raja Grapindo Persada, Jakarta, hal., 132
}

Selain sumber kekayaan mineral yang terkadung di dalam hutan Elang Dodo. Hutan Elang Dodo juga memiliki potensi yang tak kalah penting. Hal ini disampaikan oleh Walhi NTB pada tahun 2003, berdasarkan hasil temuan atau investigasinya: ${ }^{16}$

a. Produksi hutan jalid (hutan untuk produksi gula merah dari pohon enau atau aren). Masyarakat rata-rata memiliki daerah kapling sekitar 4-5 hektar untuk setiap kepala keluarga.

b. Di dalam hutan tersebut juga terdapat tanaman kemiri dan kopi, baik yang tumbuh dengan cara alami (liar) dan secara sengajah dipelihara oleh masyarakat sebagai salah satu tanaman ekonomis.

c. Di lokasi hutan Elang Dodo ternyata telah menyimpan banyak pohon gaharu (kayu mampis) dan rotan yang sampai sekarang menjadi salah satu mata pencaharian penduduk.

d. Di wilayah ini juga menyimpan madu berkualitas tinggi dengan kadar air hanya mencapai $18 \%$ (setara dengan Madu Arab).

e. Diantara beberapa pohon kayu yang sangat berharga tersebut di atas terdapat pula beberapa macam pohon kayu yang memiliki nilai yang sangat tinggi, seperti pohon kayu manis yang mempunyai banyak manfaat sebagi bahan kosmestik dan sebagai bahan penyedap rasa.

Wajar masyarakat Desa Lebangkar selain memanfaatkan sawah, kebun dan ladang, juga memanfaatkan hutan Elang Dodo sebagai tempat mata pencahariannya. Sayang pemanfaatan tersebut mulai merasa berkurang. Hal ini didasarkan pada

\footnotetext{
${ }^{16}$ Salamudin Daeng, 2006. Mengapa Rakyat Sumbawa Melawan Newmont. Foto copy Narmada, Mataram-NTB, hal,. 86-87
} 
penuturan warga Lebangkar, bahwa ketika ekplorasi PT. Newmont di hutan Elang Dodo pada tahun 2003. Kebiasan yang dilakukan oleh masyarakat Desa Lebangkar memanfaatkan hasil hutan Elang Dodo mendapat batasan dari pihak PT. Newmont. Pihak PT. Newmont merasa bahwa apa yang dilakukan oleh warga Lebangkar dapat mengangu ekplorasi PT. Newmont. Akibat dari itu sehingga masyarakat Desa Lebangkar mengalami kekurangan sumber pendapatan sehari-hari.

3. Tidak adanya sosialisasi

Kegiatan ekplorasi yang dilakukan oleh PT. Newmont di wilayah hutan Elang Dodo, merupakan rangkaian kegiatan perluasan wilayah kontrak karya PT. Newmont yang telah disepakati dengan pemerintah pada tahun 1986. Kejadian ekplorasi ini terjadi pada tahun 2003. Berdasarkan hasil penelitian, selama atau pada saat ekplorasi PT. Newmont di wilayah tersebut, tidak sedikitpun, baik pemerintah daerah atau PT. Newmont melakukan sosialisasi kepada masyarakat Desa Lebangkar terkait ekplorasi PT. Newmot di wilayah tersebut. Sehingga masyarakat Desa Lebangkar merasa dirugikan, karena tempat ekplorasi PT. Newmont tersebut adalah tanah leluhur masyarakat yang sampai saat ini masih dimanfaatkan sebagai tempat ritualitas (misalnya pada hari raya besar keagamaan mereka bersilaturahmi kekuburuan leluhurnya), perkebunan, mengambil madu, berburu dan lain-lain.

4. Penguasaan sumberdaya alam menggunakan kekuasaan.

Berdasarkan hasil penelitian, jauh sebelum ekplorasi perusahaan PT. Newmont di Block VII sudah tercium rencana akan melakukan ekplorasi di Block VII oleh para pejabat tinggi di Sumbawa seperti Camat Ropang, Koramil, Anggota DPRD Sumbawa dan masyarakat lain yang bukan berasal dari Desa Lebangkar, sehingga para oknumoknum itu memanfaatkan kesempatan tersebut untuk mengguasai atau memiliki hutan Elang Dodo dengan menggunakan SPPT.

Keberadaan SPPT tersebut, apabila dikaji secara yuridis atau melalui undangundang yang berlaku, dalam hal ini UndangUndang Nomor 12 Tahun 1994 Tentang Perubahan Atas Undang-Undang Nomor 12 Tahun 1985 Tentang Pajak Bumi Dan Bangunan Pasal 1, yang berbunyi:

Merubah beberapa ketentuan dalam undang-undang Nomor 12 tahun 1985 tentang pajak bumi dan bagunan sebagai berikut:

1. Objek pajak yang tidak dikenakan pajak bumi dan bagunan adalah objek pajak yang;

a. Digunakan semata-mata untuk melayani kepentingan umum di bidang ibadah, sosial, kesehatan, pendidikan dan kebudayaan nasional, yang tidak dimaksudkan untuk memperoleh keuntungan.

b. Digunakan untuk kuburan, peninggalan purbakal, atau yang sejenisnya degan itu; 
c. Merupakan hutan lindung, hutan suaka alam, hutan wisata, taman nasional, tanah penggembalaan yang dikuasai oleh desa, dan tanah negara yang belum dibebani suatu hak

d. Digunakan oleh perwakilan diplomatik, konsulat berdasarkan asas perlakuan timbal balik

e. Digunakan oleh badan atau perwakilan organisasi internasional yang ditentukan oleh Menteri Keuangan

Pernyataan di atas, bila dikaitkan dengan eksistensi hutan Elang Dodo yang dikuasai oleh oknum atau masyarakat di luar Desa Lebangkar dengan menggunakan SPPT, maka secara hukum tindakan itu dapat dibatalkan.

\subsection{Upaya Penyelesaian Sengketa}

3.3.1. Upaya penyelesaian sengketa yang sudah di tempuh

Inti dari teori pluralisme hukum yang disampaikan oleh John Griffiths, bahwa bukan hanya hukum negara yang berlaku tengah-tengah masyarakat, akan tetapi ada hukum lain, berupa hukum rakyat, agama dan lain-lain. ${ }^{17}$ Kajian ini apabila dikaitkan dengan permasalahan, maka dua sistem hukum yang berlaku di tengah-tengah masyarakat yang digunakan, yaitu hukum negara dan hukum rakyat. Hukum negara menggangap bahwa hutan Elang Dodo merupakan hutan negara yang didasarkan pada Keputusan Menteri Pertanian RI Nomor

\footnotetext{
17 John Griffiths, 1986. "What Is Legal Pluralism". Dalam Jurnal Of Pluralism And Unofficial Low, Number, 24 Published By The Foundation For Journal Of Legal Pluralism.
}

756/Kpts/Um/10/1982 tanggal 12 Oktober 1982, sedangkan hukum rakyat menggangap bahwa hutan Elang Dodo merupakan tanah leluhur dan wilayah tempat ritualitas keagaman. Kejadian ini tentu menggunakan dua sistem hukum yakni hukum negara dan hukum rakyat dalam melakukan upaya penyelesaian. Hukum negara menggunakan cara litigasi atau menggunakan keputusan pengadilan, sedangkan hukum rakyat lebih di kenal pada non litigasi, yang berarti penyelesaian perkara di luar pengadilan, di mana diberi kesempatan lebih luas kepada masyarakat untuk menentukan pilihan terbaik guna menyelesaikan perkara tersebut. ${ }^{18}$ Di dalam Antropologi hukum di kenal penyelesaian sengketa yang terjadi dalam masyarakat moderen maupun masyarakat tradisional. Hal ini disampaikan oleh Nader dan Todd, bahwa cara mengakhiri sengketa, ada beberapa cara; membiarkan saja atau lumping it, mengelak (avoidace), paksa atau coercion, perundingan (negosiasi), mediasi (mediation), arbitrase, dan peradilan (adjudication). ${ }^{19}$ Bukan hanya itu saja, S Robert juga mengemukakan cara untuk menyelesaikan sengketa di dalam masyarakat adat, yakni dengan cara penggunaan kekerasan, melalui upacara atau ritual misalnya upacara adat,

\footnotetext{
${ }^{18}$ I Made Widayana, 2007, op. cit, hal., 71

${ }^{19}$ Laura Nader dan Harry F. Tood Jr. 1978. The Disputing Process Law In Ten Societies. Columbia University Press, New York, hal., 9
} 
mempermalukan, melalui mahluk-mahluk supranatural, pengucilan, dan melalui pembicaraan (negosiasi maupun menggunakan bantuan pihak ketiga). ${ }^{20}$

Pernyataan teori di atas, bila hubungkan dengan upaya sudah di tempuh dalam penyelesaian sengketa tersebut oleh para pihak yakni menggunakan hukum rakyat dan hukum negara. Hukum rakyat di mulai dengan aksi sepihak dengan cara kekerasan kemudian dilanjutkan dengan membicarakan langsung dengan pihak lawan (negosiasi). Aksi sepihak dengan cara kekerasan yakni berawal dari hasil investigasi yang tidak diakui oleh pihak pemerintah dan PT. Newmont terhadap hakhak masyarakat Desa Lebangkar yang ada di hutan Elang Dodo, sehingga melahirkan pemboikotan (menghentikan secara paksa) aktivitas ekplorasi PT. Newmont di hutan Elang Dodo oleh masyarakat Desa Lebangkar. Akibat dari itu, Pemerintah Sumbawa dan PT. Newmont mengambil inisiatif untuk melakukan negosiasi dengan masyarakat Desa Lebangkar, yaitu diawali dengan sosialisasi hasil investigasi di kantor Desa Lebangkar. Pertemuan ini tidak berhasil dikarenakan perbedaan persefsi antara masyarakat dengan Pemerintah Sumbawa tentang status hutan Elang Dodo. Pemerintah menggangap bahwa hutan Elang Dodo merupakan hutan negara sedangkan

\footnotetext{
${ }^{20}$ Simon Roberts, 1979. Order And Dispute: An Introduction To Legal Anthropology. Harmonsworth; Penguin Books, hal,. 57-59
}

menurut masyarakat bahwa hutan Elang Dodo adalah tanah leluhur dan wilayah adat istiadat. Akibat dari itu, sehingga pihak pemerintah mengeluarkan kata-kata yang tidak menyenangkan bagi masyarakat. Tahapan sosialisasi itu berujung pada tindakan anarkis atau penggunaan kekerasan.

Akibat dari itu Bupati Sumbawa berinisiatif untuk menyelesaikan persolan tersebut. Bupati Sumbawa menggangap masalah itu kemungkinan besar akan menimbulkan intabilitas bagi investasi pertambangan di Kabupaten Sumbawa. Atas pertimbangan itu, akhirnya bupati menggadakan negosiasi yang kesekian kalinya dengan masyarakat Desa Lebangkar di kantor Bappeda Kabupaten Sumbawa yang di pimpin langsung oleh Bupati. Negosiasi ini menemukan titik temu antara masyarakat Desa Lebangkar dengan Pemerintah Sumbawa dan PT. Newmont yang disepakati dan ditelurkan dalam bentuk surat pernyataan bersama. Surat pernyataan bersama tersebut merupakan cara penyelesaian secara negosiasi.

Negosiasi itu tidak maksimal dikarenakan surat pernyataan bersama antara masyarakat Desa Lebangkar dengan PT. Newmont dan Pemerintah Kabupaten Sumbawa, secara langsung telah merugikan masyarakat Desa Lebangkar. Sehingga masyarakat Desa Lebangkar melakukan gerakan demontrasi. Demontrasi ini bukan hanya masyarakat Desa Lebangkar akan 
tetapi di dukung dan dilakukan oleh masyarakat Sekecematan Ropang dengan tuntutan, bukan hanya pengakuan terhadap hak masyarakat Desa Lebangkar yang ada di hutan Elang Dodo, akan tetapi tuntutan untuk sosialisasi pertambangan ke masyarakat lingkar tambang dan menolak keberadaan tambang karena dapat merusak lingkungan. Sebagai respon untuk menimalisir gerakan itu, sehingga pihak pemerintah dan PT. Newmont bersedia bernegosiasi yang kesekian kalinya dengan masyarakat dengan jalan memberi bantuan sebesar 10 milyar untuk pemberdayaan masyarakat, tapi pihak pemerintah dan PT. Newmont tidak mengindahkan hal tersebut, sehingga masyarakat marah yang berujung pada pembakaran Camp PT. Newmont di hutan Elang Dodo. Akibat pembakaran tersebut, pihak PT. Newmont dan Pemerintah Sumbawa, akhirnya menempuh jalur litigasi dengan cara melapor ke pihak berwajib terkait pembakaran camp PT. Newmont yang dilakukan oleh masyarakat Kecamatan Ropang

\section{B. Efektifitas penyelesaian sengketa}

Menurut Soerjono Soekanto, bahwa masalah pokok penegakan hukum sebenarnya terletak pada faktor-faktor yang mempengaruhinya. Adapun faktor-faktor yang mempengaruhi penegakan hukum atau efektifitas hukum: ${ }^{21}$

1. Faktor hukum itu sendiri (UU maupun keputusan)

2. Faktor penegak hukum yakni pihakpihak yang membentuk maupun menerapkan hukum

3. Faktor sarana atau fasilitas yang mendukung penegakan hukum

4. Faktor masyarakat, yakni lingkungan di mana hukum tersebut berlaku atau diterapkan

5. Faktor kebudayaan yakni sebagai hasil karya, cipta dan rasa yang didasarkan pada karsa manusia di dalam pergaulan hidup

Apabila dihubungkan dengan efektifitas penyelesaian sengketa usaha pertambangan di wilayah hutan Elang Dodo, maka penyelesaian sengketa yang dilakukan oleh para pihak yang bersengketa, baik menggunakan non litigasi maupun litigasi justru tidaklah efektif, dikarenakan berbagai faktor:

1. Substansi hukum (hukum itu sendiri)

Surat pernyataan bersama yang telah dibuat dan disepakati antara masyarakat Desa Lebangkar dengan PT. Newmont dan Pemerintah Kabupaten Sumbawa pada tanggal 4 September 2004 justru tidak bermanfaat bagi masyarakat Desa Lebangkar. Surat pernyataan bersama lebih mengguntungkan pihak PT. Newmont, karena PT. Newmont tetap eksis melakukan usaha ekplorasi di

21 Soerjono Soekanto, 2010. Faktor-Faktor Yang Mempengaruhi Penegakan Hukum. Cetakan 9, Rajawali Pres, Jakrta, hal., 8-9 
wilayah hutan Elang Dodo, tapi disisi lain masyarakat tidak diperbolehkan untuk mengakses pendapatan ekonomi dan adat istiadat di hutan Elang Dodo dengan alasan menjaga keamanan.

2. Budaya hukum

Sebagai sikap masyarakat Desa Lebangkar terhadap tidak patuhnya terhadap penyelesaian tersebut. Masyarakat Desa Lebangkar tetap memanfaatkan hutan Elang Dodo sebagai tempat mata pencaharian dan tetap melestarikan budaya nenek moyangnya. Seperti ziarah kubur yang dilaksanakan pada tanggal 26 November 2011 atau bertepatan dengan suasana Idul Adha. Ziarah ini dilaksanakan selama tiga hari penuh oleh masyarakat Desa Lebangkar. Tidak hanya itu, demontrasi juga dilakukan oleh masyarakat Sekecamatan Ropang pada tanggal 1 April 2008 yang ditujukan ke kantor PT. Newmont dan Pemda Sumbawa mereka menolak ekplorasi PT. Newmont diwilayah hutan Elang Dodo.

3. Struktur hukum (penegak hukum)

Penangkapan warga Kecamatan Ropang akibat pembakaran camp PT. Newmont di hutan Elang Dodo pada tahun 2006 yang lalu oleh pihak kepolisian atas laporan pihak PT. Newmont dan Pemda Sumbawa. Para warga tersebut di proses secara litigasi atau menggunakan hukum Negara yang berakhir pada ponis atau menjalankan hukuman 2 tahun penjara, tapi sayang proses tersebut tidak dibarengi oleh struktur hukum untuk melakukan pembinaan dan membagun kesadaran hukum masyarakat, khususnya masyarakat Desa Lebangkar. Sehingga menyebabkan terjadinya aksi demontarasi yang dilakukan oleh masyarakat berulang kali. Bahkan melibatkan elemen masyarakat lain untuk menolak ekplorasi PT. Newmont di hutan Elang Dodo hingga dengan sekarang.

\section{PENUTUP}

\subsection{Simpulan}

Adapun simpulan yang dapat dikemukakan dalam penulisan ini, yakni:

1) Subyek yang bersengketa adalah masyarakat Desa Lebangkar dengan PT. Newmont dan Pemerintah Kabupaten Sumbawa, sedangkan obyek sengketa yakni kontrak karya hasil penciutan VI pada tahun 2005 dengan luas $87.500 \mathrm{Ha}$.

2) Proses terjadinya sengketa berawal dari ekplorasi PT. Newmont di hutan Elang Dodo yang dilakukan pada tahun 2003. Ekplorasi ini melahirkan beberapa faktor yang menyebabkan sengketa, yakni; (1) dilanggarnya kebiasaan (adat istiadat), (2) berkurangnya sumber pendapatan, (3) tidak adanya sosialisasi, (4) adanya penguasaan sumberdaya alam hutan Elang Dodo menggunakan SPPT oleh 
para pejabat Pemerintah Kabupaten Sumbawa.

3) Upaya-upaya yang sudah di tempuh dalam penyelesaian sengketa ini, yakni melalui jalur litigasi menggunkan hukum negara dan non litigasi menggunakan hukum adat. Non litigasi dengan cara kekerasan dan dilanjutkan dengan negosiasi. Litigasi di proses melalui pengadilan. Penyelesaian itu tidak efektif dikarenakan faktor; (1) substansi hukum berupa surat pernyataan bersama yang lebih mengguntungkan pihak PT. Newmont dan justru merugikan pihak masyarakat Desa Lebangkar, (2) budaya hukum berupa sikap masyarakat Desa Lebangkar tidak patuhnya terhadap penyelesaian tersebut, di mana mereka tetap memanfaatkan hutan Elang Dodo sebagai tempat mata pencaharian dan melestarikan budaya nenek moyangnya. Selain itu, juga melakukan demontrasi yang ditujukan ke kantor PT. Newmont dan Pemda Sumbawa, (3) struktur hukum (penegak hukum), tidak ada pembinaan dari pihak penegak hukum dan membagun kesadaran hukum kepada masyarakat Desa Lebangkar. Sehingga menyebabkan terjadinya aksi demontrasi yang dilakukan berkali-kali oleh masyarakat.

\subsection{Saran}

$$
\text { Adapun saran yang dapat }
$$
disampaikan dalam penelitian adalah: a. Disarankan kepada Badan Pelayanan PBB Kabupaten Sumbawa untuk membatalkan penerbitan SPPT hutan Elang Dodo karena bertentangan dengan Undang-Undang Nomor 12 Tahun 1994 Tentang Perubahan Atas UndangUndang Nomor 12 Tahun 1985 Tentang Pajak Bumi Dan Bangunan Pasal 1.

b. Disarankan kepada PT. Newmont untuk menghargai dan menghormati adat istiadat yang tumbuh dan hidup dalam masyarakat Kabupaten Sumbawa, khususnya masyarakat Desa Lebangkar.

c. Disarankan kepada Pemerintah:

a. Disarankan kepada pemerintah daerah maupun pemerintah pusat untuk merevisi atau merubah keputusan kontrak karya tentang penciutan VI seluas 87.500 Ha. Keputusan tersebut secara langsung bertentangan dengan adat istiadat masyarakat Desa Lebangkar atau bertentangan dengan Pasal 18B ayat 2 UUD 1945tersebut.

b. Disarankan kepada Pemerintah Sumbawa untuk menjalankan amanat Pasal 18B ayat 2 UUD 1945 dengan cara mengakui secara sah keberadaan masyarakat Desa Lebangkar beserta hak ulayatnya yang ada di hutan Elang Dodo dengan cara membuat Peraturan Daerah (PERDA) tentang masyarakat adat. 
c. Disarankan kepada Pemerintah Sumbawa, kedepanya sebelum melaksanakan usaha pertambangan terlebih dahulu melakukan sosialisasi kepada masyarakat sekitar usaha pertambangan. Sehingga dalam pelaksanaan usaha pertambangan tidak ada pihak yang merasa dirugikan.

\section{DAFTAR PUSTAKA}

Anonim, 2011. "Potensi NTB". Serial Online Juli, Available From: URL: hhtp://ntb.go.id/deskripsiwilayah/petas umberdayaalam.

Daeng, Salamudin, 2006. Mengapa Rakyat Sumbawa Melawan Newmont. Foto copy Narmada, Mataram-NTB.

2010. Investment Colonial Model (Critical Analysis On Investment Law In Indonesia). Institute For Global Justice (IGJ), Jakarta Selatan.

Departemen Pertambangan RI, 2004. "Luas Areal Kontrak Karya PT.Newmont". Jakarta, tertanggal 12 Maret.

Gaung, NTB, 2004. "PT. Newmont Memberi Kontribusi Bagi Masyarakat Sekitar”. Tanggal 25 September. , 2004. "Penyanderaan Dua Staff PT. Newmont Oleh Masyarakat Desa Lebangkar". Tanggal 23 Oktober. Griffiths, John, 1986 "What Is Legal Pluralism”. Dalam Junal Of Pluralism
And Unofficial Law, Number 24, Published By The Foundation For Journal Of Legal Pluralism.

Salim, H, HS, 2004. Hukum Pertambangan Di Indonesia. PT. Raja Grafindo Persada, Jakarta.

IMC, 2006. "Kronologis Penembakan Warga Desa Ropang Dalam Aksi Penolakan PT Newmont”. Serial Online Pebruari 2011, Available From: URL: hhtp:/www.aifk. multiply.com

JATAM, $2006 . \quad$ "PT. Newmont Memperluaskan Kerusakan Hutan Elang Dodo". Serial Online Pebruari 2011, Available From: URL: hhtp:/www.jatam.or.

Kriekhoff, Valerine J.L, 2001. Mediasi (Tinjauan Dari Segi Antropologi Hukum). Dalam Antropologi Hukum: Sebuah Bunga Rampai oleh T.O. Ihromi. Yayasan Obor, Jakarta.

Martitah dan Abduh S, Hery, 2005. Buku Ajar Hukum Acara PTUN. UGM, Yogyakarta

Nader, Laura dan F. Tood Jr, Harry, 1978. The Disputing Process Law In Ten Societies . Columbia University Press, New York.

Soekanto, Soerjano, 1988. Pokok Sosiologi Hukum. PT. Raja Grapindo Persada, Jakarta , 2010. Faktor-Faktor

Yang Mempengaruhi Penegakan 
Hukum, Cetakan 9, Rajawali Pres, Jakarta.

Supancana dkk, 2009. Penyelesain Sengketa

Di Bidang Pertambangan. Badan Pembinan Hukum Nasional

Departeman Hukum dan HAM, Jakarta.

Program Studi Magister Ilmu Hukum, Program Pasca Sarjana Universitas Udayana, 2005. Pendoman Penulisan Usulan Penelitian Dan Penulisan Tesis Ilmu Hukum.

Roberts, Simon, 1979. Order And Dispute: An Introduction To Legal Anthropology. Harmonsworth; Penguin Books

Widyana, Made, 2007. Alternatif Penyelesaian Sengketa (ADR). Indonesia Business Law Center (IBLC), Jakarta.
Peraturan perundang-undangan

Undang-Undang Republik Indonesia Nomor 11 Tahun 1967 Tentang Ketentuan Pokok Pertambangan (Lembaran Negara Republik Indonesia Nomor 22 Tahun 1967).

Undang-Undang Republik Indonesia Nomor 41 Tahun 1999 Tentang Kehutanan (Lembaran Negara Republik Indonesia Nomor 167 Tahun 1999).

Undang-Undang Republik Indonesia Nomor 4 Tahun 2009 Tentang Pertambangan Mineral Dan Batu Bara (Lembaran Negara Republik Indonesia Nomor 4959 Tahun 2009).

Kontrak Karya Antara Pemerintah Republik Indonesia Dan PT. Newmont, yang telah dibuat dan disepakati pada tanggal 2 Desember 1986 di Jakarta. 


\section{LAMPIRAN}

\section{BIODATA PENULIS}

$\begin{array}{llll}\text { Nama } & : & \text { Iwan Harianto, SH } \\ \text { Alamat Rumah } & : & \text { Dusun Masjid RT/RW 002/001 Desa Empang Bawa } \\ & & \text { Kecamatan Empang Kabupaten Sumbawa Propinsi NTB } \\ \text { Tempat Bekerja } & : & - \\ \text { Pendidikan } & : & \text { S1 Ilmu Hukum } \\ \text { Pengalaman } & : & \text { Aktif di Komite Wilayah NTB Serikat Tani Nasional (STN) } \\ \text { Nomor Hp } & : & \text { mulai tahun 2011 sampai sekarang. } \\ \text { Alamat E-mail } & : & \text { iwanhariantosh@ gmail.com }\end{array}$

